\title{
Especialidades Médicas - Radiologia
}

\section{Regina Lucia Elia Gomes}

\begin{abstract}
A Radiologia entrou em minha vida durante o terceiro ano da faculdade, através da aula do Dr. Nelson Roque Paladino, que mostrava as imagens das radiografias de tórax com maestria, com a discussão voltada principalmente para o coração, despertando minha atenção para a especialidade. Depois, durante o internato, as excelentes aulas sobre ultrassonografia de tórax do Dr. Miguel José Francisco Neto, radiografia de tórax do Dr. Ricardo Masseti Guerrini, ultrassonografia de abdômen do Prof. Dr. Giovanni Guido Cerri, tomografia computadorizada de crânio do Dr. Nélio Garcia de Barros e radiografia e tomografia computadorizada do abdômen do Prof. Dr. Manoel de Souza Rocha fizeram com que eu optasse pela especialidade, já uma das mais concorridas na época. Essas aulas encantadoras nos mostram que a responsabilidade dos professores e médicos voltados para a atividade acadêmica não se restringe à aula propriamente dita, vai muito mais além, chegando a influenciar a opção pela carreira a ser seguida, dependendo do entusiasmo com a qual é dada. Some-se a isso também a experiência anterior no ginásio e no colegial, que veio a ajudar a definir a opção através da contribuição de algumas matériaschave como biologia (com o enfoque na anatomia), desenho geométrico (com suas vistas e projeções) e matemática (com o conceito de matriz), todas elas muito relacionadas com a Radiologia. Consegui juntar todas as áreas que gostava, antes e durante a graduação, numa só especialidade, sendo, portanto, plenamente realizada profissionalmente.
\end{abstract}

A minha residência médica em Radiologia foi muito interessante, gratificante e instigante, com corpo docente de alto nível, embora naquela época o parque tecnológico do Departamento não fosse tão atualizado quanto agora. Foi também muito divertida, porque não dizer? Havia um entrosamento entre os colegas residentes de Radiologia dos vários anos e uma harmonia que tornavam ainda mais feliz minha escolha, criando um ambiente de trabalho muito agradável, onde ganhei grandes amigos com vários dos quais convivo e trabalho até hoje. Minha turma de residentes foi uma das primeiras a ter o terceiro ano oficial, e, antes do término do curso, fizemos um abaixo-assinado solicitando a criação do quarto ano, a nosso ver imprescindível na formação do médico radiologista, que foi aceita e perdura até hoje. Naquela época a especialização do quarto ano era por aparelhos (ultrassonografia, tomografia computadorizada e ressonância magnética), mas atualmente, já há muitos anos, exceto na ultrassonografia, é por grupos (abdômen, cabeça e pescoço, mama, músculo-esquelético, neuro, pronto-socorro, tórax e vascular-intervenção). Isso se deve à enorme abrangência da especialidade, não sendo possível dominar o conhecimento de todas as áreas. O radiologista é um dos médicos que deve ter o maior conhecimento geral sobre a medicina.

Gosto muito de ensinar, dar aulas e conviver com os residentes, que são um estímulo para que eu me mantenha atualizada, e cuja energia jovial é contagiante! Minha satisfação pessoal com a profissão é tamanha que não me importo de ainda dar plantões nos finais de semana em meu trabalho no setor privado, agora apenas diurnos, pois é gratificante sentir que você pode contribuir, fazer a diferença na condução de um caso. Além disso, o convívio com os colegas especialistas das respectivas áreas também é gratificante, há uma troca de experiência e um aprendizado constante, como ao discutirmos um caso nas reuniões multidisciplinares, na rotina, no plantão ou ao confirmarmos um caso pelo resultado anatomopatológico.

Por outro lado, a especialidade apresenta algumas dificuldades, tais como dependência de

Coordenadora dos Programas de Residência Médica do Departamento de Radiologia da FMUSP. 
atualização constante dos aparelhos, que são caros, manutenção onerosa dos mesmos, desafio de dominar todas as áreas na maioria dos serviços que não adotam a divisão da especialidade em grupos. Entre as dificuldades, embora muito raras atualmente, as reações alérgicas aos meios de contraste devem ser lembradas, sendo necessário que o local do exame tenha todos os recursos para dar o suporte a uma eventual reação. Para isso também é necessário que o radiologista seja treinado para dar os primeiros socorros até que a equipe de apoio chegue, e esse treinamento deve ser reciclado com frequência. Outra dificuldade com a qual nos deparamos é a falta de dados clínicos fornecida nos pedidos de exame, principalmente fora dos meios acadêmicos, o que prejudica a escolha do protocolo ideal de exame. Os colegas das demais especialidades não tem noção de como isso pode impactar no resultado final do exame. Um simples dado clínico com os objetivos do exame no pedido faz toda a diferença, pois temos muitos protocolos disponíveis para realizar um mesmo exame e a escolha do protocolo ideal depende de informações que nem sempre os pacientes sabem nos fornecer.

O mercado de trabalho é variável, depende muito do aquecimento da economia, agora passa por um momento de valorização do profissional, com alta demanda, absorção imediata ao término da residência e maior rotatividade entre os mais experientes, mas já houve épocas de recessão nas quais só se empregava em locais da periferia da cidade e com má remuneração. Essa relação direta com o quadro econômico se justifica em virtude de que tanto os meios de contraste quanto os aparelhos de imagem são importados, portanto as dívidas são em dólares.

A rotina do radiologista consiste basicamente em saber fazer o exame pessoalmente ou saber orientar sua execução ao técnico ou biomédico; fazer a análise critica do pedido de exame; conhecer as indicações e as contraindicações dos diversos métodos; laudar o exame, interpretando-o, correlacionando-o aos achados obtidos com os dados clínicos fornecidos pelo médico e/ou pelo paciente. Deve também ter uma boa base de física, para entender a obtenção das imagens, sempre procurando melhorá-la, realizando uma documentação de alta qualidade do exame. Além disso, o radiologista desempenha funções administrativas nos grandes serviços, contribuindo para a escolha de equipamentos, realização de contratos de compra e de manutenção, atualização de protocolos de exame. A parte acadêmica consiste em dar aulas à graduação e ensinar os residentes a conhecer os aparelhos, saber manipulá-los, aprender a orientar e laudar, corrigir seus laudos, e, principalmente, passar sua experiência e eles, algo que não está nos livros e que agrega valor à formação do residente. A parte científica é realizada através da execução de painéis e temas livres para congressos nacionais e internacionais, redação de artigos científicos e de capítulos de livros para publicação. O radilogista também procura se manter atualizado, freqüentando ou dando aulas em congressos nacionais e internacionais.

O salário inicial depende muito do local onde se trabalha. O serviço público, como nas demais especialidades, remunera muito mal, sendo atraente apenas pela diversidade de doenças, pela possibilidade de atividade acadêmica e científica. $\mathrm{O}$ serviço privado remunera melhor que o público, em geral, e com as práticas de boa gestão adotadas pelos grandes serviços, chega a ter planos de carreira, com transparência na mudança dos níveis salariais, com valorização do curriculum através da educação médica continuada e da pós-graduação. Atualmente, também o serviço privado tem se interessado em desenvolver a atividade acadêmica e científica, competindo pelos melhores talentos com o serviço público, que cada vez mais tem dificuldade em retê-los. Os valores pagos pelo serviço privado também variam, às vezes são maiores em regiões mais distantes dos grandes centros.

Os preconceitos em relação à especialidade são decorrentes do medo da exposição excessiva à radiação ionizante, o que não ocorre muito hoje em dia com a utilização adequada dos equipamentos de proteção individual, exceto para os radiologistas que trabalham com intervenção, estes ainda submetidos a uma dose maior que os demais. Outro preconceito ocorre por alguns exames serem operador-dependente, como a ultrassonografia, havendo necessidade de confiança no relatório, pela dificuldade de avaliação das imagens obtidas em tempo real. Por outro lado, as radiografias e os métodos seccionais como tomografia computadorizada e ressonância magnética, por terem suas imagens facilmente disponíveis, antigamente em filmes e agora em CDs ou no PACS, fazem com que alguns colegas de outras especialidades ignorem os laudos dos radiologistas e eles próprios interpretem as imagens, por vezes incorrendo em erros.

Os mitos se aplicam mais aos pacientes, com medo da radiação ionizante e da ressonância magnética, sendo que inclusive esta, antigamente, apresentava o termo nuclear associado, abolido para evitar assustar os pacientes. Entre os colegas, há o 
mito que o radiologista trabalha pouco, fato que não corresponde à realidade, a começar pela residência, com carga horária completa nos 3 anos e no ano de especialização, e plantões em todos os anos, além do exercício profissional depois ser também intenso, com alta demanda de exames e em geral com plantões, que vão gradativamente dos noturnos para os diurnos com o passar do tempo. Outro mito é que o radiologista não tem contato com o paciente, pois em vários exames esse contato é direto, e em alguns como os intervencionistas, sua responsabilidade é tal a ponto de haver contanto antes, durante e depois do procedimento, assemelhando-se às demais especialidades onde há uma relação médico-paciente mais duradoura.

Enfim, a Radiologia é uma grande especialidade! 